7. Сучасна політична лексика : енциклопед. словник-довідник / [I. Я. Вдовичин, Л. Я. Угрин, Г. В. Шипунов та ін.]; за наук. ред. Хоми Н. М. Львів, 2015. 396 с.

8. Філософія: Навчальний посібник / І. Ф. Надольний, В. П. Андрущенко, І. В. Бойченко, В. П. Розумний та ін.; За ред. І. Ф. Надольного. Київ, 1997. 584 с.

9. Шляхтун П. П. Політологія (теорія і історія політичної науки). Київ, 2002.576 с.

DOI https://doi.org/10.30525/978-9934-588-91-4-39

\title{
МІСЦЕ УКРАЇНИ В СУЧАСНІЙ СИСТЕМІ СВРОПЕЙСЬКОЇ БЕЗПЕКИ
}

\author{
Тімкін І. Ф. \\ кандидат історичних наук, доцент, \\ доцент кафедри соиіальних технологій факультету лінгвістики та \\ соиіальних комунікацій \\ Національного авіаційного університету \\ м. Київ, Украӥна \\ Новікова Н. С. \\ старший викладач кафедри сочіальних технологій факультету \\ лінгвістики та сочіальних комунікацій \\ Національного авіаційного університету \\ м. Київ, Украӥна
}

Нова геополітична ситуація у світі характеризується протистоянням ключових суб'єктів системи європейської безпеки (з одного боку США, НАТО та ЄС, з іншого-Росії).

3 часу створення $\mathrm{CC}$ західні держави гальмували розвиток його оборонних ресурсів, які формально передбачені в установчих договоpax. Європа залишилась у стані стратегічної військово-політичної та військово-технологічної залежності від НАТО і США. Асиметрія американо-європейських політичних можливостей очевидна і у НАТО, де США забезпечує три чверті витрат. Станом на 2013 рік витрати на оборону в державах Свропи у порівнняні за періоди першої половини 90-х років загалом скоротилися з 2,5 до 1,6 \% ВВП. Зазначені тенденції призвели до ситуації, коли європейці не здатні себе захистити від військової агресії [1]. 
Однак, зростання територіальної згрози, агресивна політика Російської Федерації, а також загострення ситуації на Корейському півострові змусили переоцінити ситуацію в оборонній сфері західних країн. Після 2014 року спостерігається зростання глобальних витрат на оборону. За підсумками 2017 року вони досягли максимального рівня після закінчення Холодної війни. У 2018 році всесвітні витрати на оборону, як очікується, зростуть на 3,3 \% і досягуть 1,67 трлн. дол., що перевищіть рекорд 2010 року який склав 1,63 трлн. дол. [1].

Такі ж тенденції спостерігаються і в країнах НАТО, які за 2018 рік збільшили свої видатки на оборону у порівнянні з попереднім роком ще на $3,82 \%$. У 2014 році країни НАТО домовилися протягом десяти років довести видатки на оборонні потреби до 2\% від обсягів ВВП. Президент США Дональд Трамп наполягає щоб союзники по НАТО досягли цього показника щонайпізніше до 2024 року. Однак, в минулому році цієї мети, крім США(3,57\% ВВП), досягли лише Греція $(2,36 \%)$, Великобританія (2,2\%) і Естонія (2,08\%) [2].

Стратегічним прорахунком вважається і той, що західні союзники по НАТО знехнували важливими для континентальної геополітики просторами Східної Свропи. Колишні республіи СРСР, зокрема Україна, отримали статус відносно сприятливих буферних територій 3 перспективами демократичного розвитку. США і Західна Свропа, фактично, віддали на відкуп Росії простори ії̈ традиційного геополітичного впливу (окрім країн Балтії) . Західний світ повірив у те, що ослаблена Росія відмовилася від імперських намірів. Не були повною мірою враховані зміи, що відбувалися у системі міжнародних відносин у першому десятилітті XXI століття: криза американської гегемонії у світовій політиці і формування багатополярної системи міжнародних відносин в умовах посилення регіональних центрів сили з глобальними амбіціями (СС, Китай, Росія).

Росія починає посилювати свої позиції на міжнародній арені. Цьому сприяли ряд факторів. По-перше, у країні відбулася зміна правлячої верхівки. Прихід до влади когорти колишніх представників КДБ СРСР та інших силових органів і лояльної до них чиновницької бюрократії дозволило взяти курс на централізацію і встановлення авторитарної системи управління державою. Сформовано систему одержавленого капіталізму 3 тотальним контролем держави за великим бізнесом. Мілітаризація економіки за рахунок нафтодоларів дозволило Росії зміцнити військову могутність держави[3]. По-друге, для Росії склалася сприятлива політична кон'юктура. Вона зміцнила політичні та економічні відносини з низкою держав СС шляхом вдалого енергетичного менеджменту через поставки газу і зрощення бізнесінтересів.

Таким чином, поблажливе ставлення демократичного світу до наростання авторитаризму в Росії, зростання іiі реваншистських настроїв у зовнішній політиці пов'язане 3 зосередженням держав та організацій 
Західного світу на власних економічних проблемах, кризою інституційно-політичного розвитку СС, невизначеністю подальних стратегічних орієнтирів розвитку НАТО.

Слабкість Заходу, насамперед країн ЄС, у відносинах з Росією наочно проявляється під час подій іiі військової агресії на території України. Свропа і США виявили неготовність до розвитку конфліткту на Сході Свропи. Після тривалих спроб умиротворити агресора засобами дипломатії, Рада ЄС прийняла рішення введення сисемних санкцій, а Верховний представник 3 питань зовнішньої політики i політики безпеки Фредеріка Могеріні 1 вересня 2014 року заявила про припинення партнерських відносиш ЄС 3 Росією. Про можливість застосування військових чи поліцейських ресурсів взагалі не йдеться. Більш жорстоку позицію по відношенню до агресивної політики Росії зайняв Альянс. Напередодні саміту НАТО в Уельсі 4-5 вересня 2014 року генеральний секретар Альянсу Андерс Фог Расмуссен зробив історичну зяаяву про те, що НАТО і Росія більше не $\epsilon$ партнерами, а $є$ противниками [3].

Поза членством в СС або НАТО Україна не може брати повноцінну участь у формуванні механізмів європейської безпеки. Підписання Угоди про асоціацію з ЄС відкриває перед Україною можливість посилити власні позиції в регіональному вимірі, надати їм нової якості.

Сьогодні очевидно, що позаблоковість України не змогла гарантувати їі суверенітет і територіальну цілісність. Слабкість системи національної безпеки i оборони, відсутність надійних зовнішніх гарантій безпеки не дозволяють Україні самостійно протистояти зростаючим зовнішнім загрозам, у тому числі воєнного характеру. 8 червня 2017 року парламент остаточно скасував позаблоковий статус України. Верховна Рада підтримала законопроект №6470 «Про внесення змін до деяких законодавчих актів України (щодо зовнішньополітичного курсу України)», який вніс зміни до законів «Про засади внутрішньої і зовнішньої політики» та «Про основи національної безпеки України». Законом у перелік основних напрямків дежавної політики 3 питань національної безпеки та основних засад зовнішньої політики України додано «поглиблення співпраці з Організацією Південноатлантичного договору з метою набуття членства у цій організації»[4].

Наближенню України до стандартів НАТО сприяє Закон «Про національну безпеку України», прийнятий Верховною Радою 21 червня 2018 року. Таким чином, курс України на членство в НАТО цілком відповідає чинному національному законодавству. Але на шляху до НАТО Україні потрібно подолати багато перешкод та невирішених завдань.

Незважаючи на зростання кількості громадян України, які підтримують вступ до євроатлантичної спільноти, залишається значна частина людей, які не визначилися зі своєю думкою щодо місця країни у 
європейській сім'ї. Та навіть серед тих, хто декларує голос на користь НАТО, висловлюється зачасту емоційно, а не свідомо.

Цю ситуацію можна пояснити, таким чином що багато людей й досі знають про НАТО лише те, що чули в радянські часи, вважаючи НАТО агресивним військовим блоком, що може втягнути Україну у війну з іншими державами.

Вони не до кінця розуміють, що НАТО змінилось кардинально. Нині це вже не військовий блок чи союз. Це безпечна організація 3 принципово новим світобаченням, новою постановкою завдань, новими проблемами та новими партненами.

Громадяни України повинні усвідомлювати, що вступ до НАТО дає не лише безпекову гарантію і підтримку у впадку військової агресії проти нашої країни. Вступ в Альянс або хоча б позитивна динаміка у стосунках з НАТО має важливий вплив на економіку країни.

Зрозуміло, що зближення з НАТО можливо при умові підвищення проінформованості наших громадян з питань євроалантичної інтеграції.

За цих умов Україна має продовжувати поглиблювати співробітництво 3 НАТО як зі стратегічним партнером. Причому не тільки у військовій сфері, а й з питань енергетичної,економічної та інформаційної безпеки.

Таким чином Україна має повне право і повинна просувати ідею вироблення загальноєвропейського механізму колетивної безпеки. Такий механізм має чітко визначити обсяг забов'язань та перелік санкцій, які будуть оперативно застосовуватися до порушників миру та безпеки.

\section{Література:}

1. Грубінко А. Криза системи європейської безпеки і умовах російсько-українського конфлікту: стратегічні підходи та інтереси Великої Британії [Електронний ресурс]/Режим доступу: Shron1/chtyvo.org.ua

2. Иноземцев В.Л. Потеряное десятилетие: монография / В. Л. Иноземцев. - М.: Московская школа политических иследований, 2013. - С. 587.

3. Росія і НАТО стали противниками. - Расмуссен. 01 вересня 2014 [Електронний ресурc] / Режим доступу: http://www.pravda.com.ua

4. Світові тенденції в оборонній галузі, що очікувати у 2018 році [Електронний ресурс] / Режим доступу: defence-ua.com 